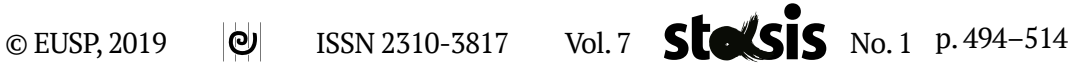

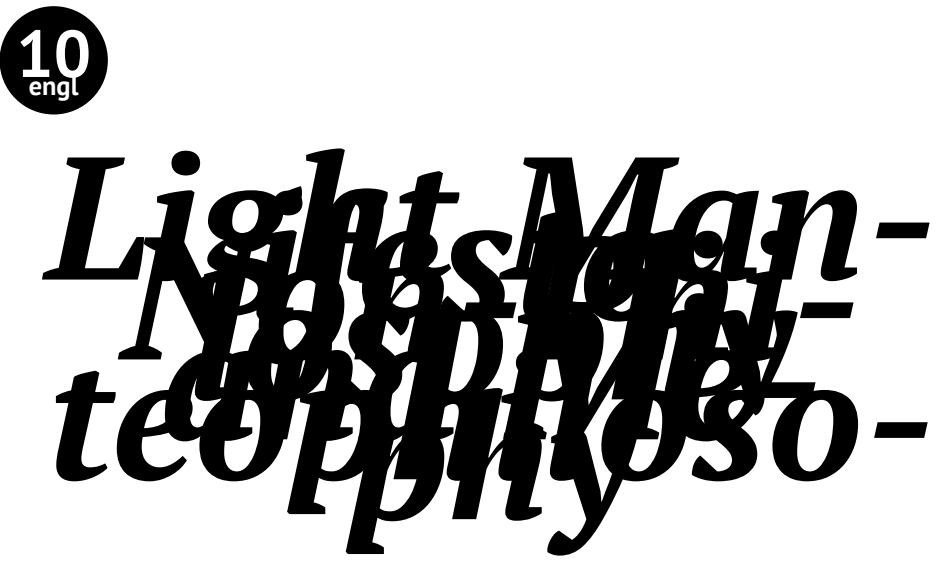

Nikita Sazonov

Research Curator, Posthuman Studies Lab, 119/246 Mira Prospekt, Moscow, Russia 129223

E-mail:darkcryptasite@gmail.com

\title{
Light Manifesto: Non-Philosophy and Meteophilosophy
}

\begin{abstract}
Deleuze's speculative suggestion on the dark precursor is not a neutral "creative" cooperation with science that his "hybrid" projects of geophilosophy, schizoanalysis, and so on, were. The dark precursor is mentioned once in Difference and Repetition as a notion of a "vaguely scientific" discipline, and there was no broad or explicit conceptual extension of it in Deleuze's further philosophy. But at the same time, this accidental usage of the dark precursor uncovers the deep and fundamental sutures of recent speculative philosophy with the physical investigation of
\end{abstract}


lightning. The fundamental questioning of philosophy, such as Quentin Meillassoux's speculative movement on "hyperchaos," is localized within the meteorological chains of the cosmic order of the principles of lightning's genesis. In such meteophilosophy, we

can find a way to suspend the transcendental limits of

logocentrism, in its logo-photo-centric edition proposed by François Laruelle. Logo-photo-centric thought constituted by the light manifesto, or by the light as Flash, can be suspended by the

anti-manifestational short-circuits of meteophilosophy's

speculative models. Such short-circuits, from the other side, constitute the core of the lightmares of thought that did not even come to Laruelle in his non-philosophical dreams.

\section{Keywords}

manifestation, light, speculative philosophy, dark precursor, nonphilosophy

Light itself is the most viscous thing of all, since nothing can surpass its speed... come in and join the fun! But I see, you are already here...

Timothy Morton

\section{Chthonic Chains}

The chthonic Greek past has bequeathed to us a legacy of the chains of Logos. We are floundering in its straps-that is, logocentrism-trying to rip them apart in many different ways. All attempts to liberate a thought from its logocentric chains today collapses into the exposure of various "centrisms": anthropocentrism, naturecentrism, eurocentrism, and so on. Symptoms of logocentrism expand as its clinical signs multiply in the chimeric logic of prefix: anthropo-euro-ethno-geo-machino-eco-phallo-... The all-too-common resistance of contemporary theory ${ }^{1}$ seems to be paradoxical: rather than defeating centrisms, contemporary theorists multiply them. The additive impulse of contemporary criticism has no oppor-

1 For instance, in General Ecology, edited by Eric Hörl (2015), I counted at least six "centrisms": logocentrism itself, biocentrism, machinocentrism, ecologocentrism, anthropocentrism, naturecentrism. Rosi Braidotti marks a similar tendency of a "sequence of prefixes that may appear both endless and somehow arbitrary" (2013: 1) with regard to posthumanism, which is (like Laruelle's logo-photo-centrism in our text) not "the nth variation" in this sequence of prefixes. 
tunity to make a shift from a description of the clinical picture of logocentric infection to an autopsy of its pathogenesis.

In his works, Derrida marked "the violence of light," the gelio-politics of logocentric Greek-Platonic thought, which suggests "the surveillance of the agency of glance and the metaphor of light" (Derrida 1978: 109). Gelio-politics "does not only enlighten: it engenders" (Ibid.: 106). It is a force of "incandescence" rather than enlightening. The traces of geliopolitical violence of light can be found in the myth of Plato's Cave, where thought is born through the copulation of eye with solar rays (Land 1992: 27-34). Encountering the Sun, the characters of Plato's parable realize that the "impact of light is (at first) pain, because of 'the dazzle and glitter of the light" (Ibid.: 29). The "truth" of logocentric thought, then, is in-lightenment, the thought originated by the traumatic penetration of the "dense materiality" of light's radiation. In the case of Cartesian cogito, such in-lightenmental outrage takes the form of an "innate" disease that strikes the very structure of thought: it is interior to thought and takes thought's transcendental outlines as the "essence of a created intellect" (Descartes 2008: 43). Natural light can be obscured by errors and prejudices, but its presence is inevitably soldered into thought's functioning (Descartes 2006: 11). The thought itself thus becomes illumination, with no reminiscence about its own mythic genesis. The "natural light" by which the cogito is charged grasps knowledge through intuitive illumination that is, at the same time, the process of thought itself. The truth of Enlightenment (as the culmination of the Cartesian project) is the fact of the complete encapsulation of the light economy, an "atrophy" of the eye (Land 1992: 29), by means of which light becomes thought's transcendental limit: not a mere metaphor, but a kind of meta-metaphor. The geliopolitical Logos, then, is a result of a burn, a blind-spot, or maculae corneae (leucoma, the light inside the eye ${ }^{2}$ ), the result of light's incandescence, which-through the shift from Plato to Descartes-becomes a condition of possibility of the eye and of the thought itself, its transparent transcendental constitution, an eternal and unescapable "point of view," or rather, logocentrism.

But how did light, which was intertwined with thought, become thought's transcendental limit, if we suppose that this transcendentality cannot be grasped as a "one more" manifestation of logocentric totality (like any other centrism)? While the basic critical impulse of contemporary theory operates through a logic of additional prefixes to the word "logocentrism" (anthropocentrism, etc.), we need to open a démarche

2 Leucoma is a "dense, white opacity of the cornea resulting from disease or injury. A leucoma near the centre of the cornea causes blindness" (Youngson 2005: 331). The word comes from the Greek leukos (white) and is also correlated with Old English leoht (light). See Kurath, Kuhn, and Lewis (1952). 
that subverts the wholeness of the word "logocentrism," incorporating a kind of conceptual "hyphen" into it. This is what non-philosopher François Laruelle (2012) reveals as a logo-photo-centrism. Dealing with such non-standard centrism, Laruelle suggests that logocentrism has a certain technological embodiment that is revealed by the "-photo-" in the term "logo-photo-centrism." That means that logocentrism is not the totality (that proliferating centrisms recalls), but rather the total "technological and moral exploitation of light" (Laruelle 2012: 38). But what exactly does this photo-exploitation means? As Laruelle suggests, the logo-photocentric limit of thought is based upon the "the most profound prejudice" (Laruelle 2012: 39), from which, according to the thought of non-philosophical deconstruction of logo-photo-centrism, no philosophical project is safe. ${ }^{3}$ This prejudice means that

the vector of the photon stream is understood as a flash closing in on itself, the Logos that does not spread itself out to the particulate state of self-belonging, the flash isolating itself as in deterministic or particle physics that would fold the stream in on itself. (Ibid.)

The isolating light, the light in the state of self-belonging or light as Flash composes, according to the thought of "non-philosophy," a sort of manifesto of light of logocentric thought. ${ }^{4}$ The manifest both as the basic (and unescapable) technological model of logocentrism-the manifestation of Flash as an "archi-originary metaphor" of the event of Logos (Ibid.)-and as a kind of "luminous" manifest image of philosophy and of logocentric thought itself. The light's manifestations (as Flash) is relevant for both platonic illumination and the Cartesian luminous act of intuition. But it is also, according to Laruelle's thought, relevant to the late versions of transcendentalism (phenomenology, fundamental ontology): "Philosophers are fascinated by the Flash [...] they do not stop short-circuiting thought and accelerating its transcendental velocity" (Ibid.: 40). Thus, Laruelle notices the total impotence of philosophy itself in the face of the Flash. The main violence of light over philosophy, then, lies in fact that philosophy can only be in a state of admiration without direct access to the creation of the Flash. "[W]e arrive too late to assist in the creation

3 Non-philosophy is not anxious about providing examples or evidence through listing projects because it per-ceives itself as a certain philosophical study of philosophy. In this regard, non-philosophical statements should address any philosophy without exception. For more on this topic, see, for example, the works of Ray Brassier $(2001,2007)$.

4 Alexander Galloway gives a good explanation of how Laruelle criticizes the light manifestation (Galloway 2013: 230-32). In this paper, I do not consider this solution since I find its movement in relation to the issue of meteophilosophy identified here somewhat trivial. 
of light, we only assist in its birth" (Ibid.: 41). Philosophy collapses, therefore, into a strange transcendental theology of the Great Photographer. The Great Photographer is an exterior principle for the creation of still "veritable immanental appearance of Flash" (Ibid.), or a strange transcendence in the transcendental constitution of thought. It is a Creator of Logos, to which philosophers-from Plato to Heidegger-still continue to pray. Philosophers are fascinated by the creation of Flash "to which in the best of cases they return in the deployed forms of Logos and Reason" (Ibid.: 40). They are blinded by the dazzle of light being imprinted on the Great Photographer's Great Photo with a smile of fascination, that is, Logos, a surplus effect of an Event of Flash.

Laruelle's arguments concerning the existence of a light manifesto are very compelling. Nevertheless, the labor of investigating it leaves much to be desired. In this article I will try to step further in the investigation of the light manifesto. I will re-interpret the relations of thought and light through the excavation of the zone of indifference between science and philosophy with regard to light, which I call meteophilosophy. Meteophilosophy, as a strange theoretical practice, suspends the logo-photo-centric limit and excavates its anti-manifestial short-circuits. Starting with the shift from fundamental ontology to a philosophy of difference (Gilles Deleuze) and beyond (Quentin Meillassoux), philosophy does not focus on the facticity of the manifest of light (i.e., Flash) but concentrates on the conditions and principles of its manifestation instead. In this speculative attitude, philosophy is moving extremely close to the physics of lightning. Deleuze's dark precursor plays the key role here because it constitutes the crucial bond in relations between science and philosophy in regard to light in the state of lightning. Meillassoux's point on "hyperchaos" extends the precursor's logics. This crossing of philosophy with the science of lightning, as I am going to demonstrate, will effect the sort of speculative principles that are the worst lightmares of thought that could not have appeared in Laruelle's non-philosophical dreams.

\section{Interlude: Philosophy, Science, and Meteophilosophy}

At the heart of Laruelle's deconstruction of logo-photo-centrism is the non-philosophical treatment of the relations between science and philosophy. Logo-photo-centrism follows from philosophy's own mode of production that Laruelle calls "principle of sufficient philosophy" (Laruelle 2013a: 5-30). This is the basic trope of the non-philosophical insurrection against philosophy, precisely the "non" in the word "non-philosophy." The principle of sufficient philosophy is a sort of "ultimate authority of philosophy over the Real," the very core of philosophical thought 
that was never renounced by "inner" types of insurrection, such as the dialectic or deconstruction (Laruelle 2013b: 14). The result of such sufficient authority is the "traditional relations which are globally those of ontological domination of philosophy over science" in the question of the Real (Ibid.: 40).

The non-philosophy that ungrounds the principle of sufficient philosophy "seeks not to supplant or eliminate philosophy but rather to use it as a material and object of study," and to unground its "innermost workings and explain its fundamental operations" like the Flash and the One (Brassier 2007: 120). Such non-philosophical usages of philosophy constitute an "autonomous theoretical practice," which is based not on a simple negation, but on an abandonment both of the very domination of philosophy over science (and vice versa), and of the difference between science and philosophy in general by producing a "unified theory of science and philosophy" (Ibid.: 10). Such non-philosophical first science "distinguishes itself from the kinds of contemporary philosophies of Difference or Multiplicities and more generally from every ontology as from every deconsstruction of ontology" (Ibid.: 37). It represents "something other" than the synthesis of philosophy and science. "Not a reform, but a new usage of philosophy and science deduced from the unseparated identity of the Real" (Ibid.: 38).

This non-philosophical reflection on "non-standard" thought's practice refers to such relations between science and philosophy is that discussed in the works of Deleuze. The starting point of such reference is the micro-polemics initiated by Deleuze in his book with Félix Guattari, What is Philosophy? (1994). Laruelle is mentioned twice in this text; the second mention is critical. As Deleuze says, "François Laruelle proposes a comprehension of nonphilosophy as the 'real (of) science,' beyond the object of knowledge... But we do not see why this real of science is not nonscience as well" (Ibid.: 234).

Such a secondary micro-polemic on the relations between science and philosophy that unfolded in the footnotes of What is Philosophy? hints at the alternative way of relinquishing the difference between them. As Deleuze notes in "Mathesis, Science and Philosophy" (2007), the starting point in this problem is the existence of a difference between science and philosophy and, as a consequence, the existence of a difference between ways of treating such difference: "It is not easy to understand the exact sense of the discussions that periodically oppose philosophers and scientists-they do not speak the same language" (Ibid.: 142). The difference in the treatment of science-philosophy relations is the very effect of the difference between philosophical and scientific modes of production, which do not allow for an intersection in their production lines. There is "a fundamental dualism [that] poses itself within knowledge, between Science and Philosophy," which was introduced by "the Cartesian opposi- 
tion between extended substance and thinking substance" (Ibid.). But, as Deleuze notes, "Descartes never renounced the unity of knowledge, the mathesis universalis" (Ibid.). In opposition to Laruelle's non-philosophy as a practice that comes after the division between science and philosophy, there is a certain zone before science and philosophy where they "tend to rediscover their lost unity." This mathesis universalis is "therefore neither a science, nor a philosophy." It is the "the level of living man," which "situates itself on a plane where the life of knowledge is identical with the knowledge of life" (Ibid.: 147).

We can say that Deleuze's philosophy is an assemblage of so many different attempts to rediscover and to retain this vitalistic mathesis by means of both philosophy and science. The ultimate example is Professor Challenger appearing in A Thousand Plateus (Deleuze and Guattari 1987). He mixes geology and biology with linguistics and psychoanalysis, and so on, to grasp the deterritorialization of the Earth (Ibid.: 40). The Challenger-fashioned way of thinking was Deleuze's own image, which is literally expressed in geophilosophy, mixing the earth sciences with philosophy. But the same goes for the project of schizoanalysis (psychoanalysis+marx ism+philosophy), "logic of sense" (mathematics+lingustics+philosophy), and specifically Deleuze's collaboration with Guattari. This is philosophy's "relation of the non-relation" with other planes of thought, a "general co-dependence and distribution," a sort of coupling and co-creation with "science, technology, literature, cinema, history, ecology, or madness" that constitutes Deleuze's own fashion of non-philosophy (Lambert 2002: xiii, 18).

However, this attempt at Great Non-Philosophy, a truly deterritoralized thought in the process of becoming-orphaned-which today has culminated into the projects of Cybernetic Culture Research Unit (CCRU), Nick Land and Reza Negarestani ${ }^{5}$-is a typical reinforcement of philosophical sufficiency that is restricted by the limit of philosophy's own ends. From the side of science-along with similar attempts by Alain Badiou on mathematics and other philosophers - the "mathetic" impulse of philosophy was treated as ridiculous and an unfit "abuse" of science by philosophy, just like the structuralist exploitation of linguistics but not as a practice that breaks through the hierarchy of philosophy over science. ${ }^{6}$ Nevertheless, as I am going to claim, Deleuze's project has in itself a strange movement through which science and philosophy become extremely close to each other, right up to the point there is a complete indiscernibility between them. And, against all suggestions that "it is hard

5 See Cybernetic Culture Research Unit (2017), Land (2011) and Negarestani (2008, 2018)

6 For more on this topic, see Gironi (2011), Tripodi (2015), Sokal and Bricmont (1999). 
to see what difference even the latest discoveries in modern physics could make, for example, to the conceptions of Berkeley, dating from the eighteenth century" (Deleuze 2007: 142), we are in a mess: Is it another "isolated" speculative principle, or is it a result of investigations in the field of physics? This kind of awkward indiscernability-which produced by Deleuze rather through his own negligence and which I called above "meteophilosophy"-is what I am going to trace through the texts of contemporary physics and philosophy.

\section{Lightning(-)flash}

Heidegger's fundamental ontology is the most relevant case in Laruelle's deconstruction of logo-photo-centrism. The model of ontic-ontological Difference is most consistent with the theology of the Great Photographer. The ontic-ontological Difference is the culmination of phenomenological admiration for the genuine wholeness of the auto-manifestation of the Flash. As Laruelle puts it,

If the flash is the archi-originary metaphor of the event of Logos, it still must serve as the model of Heideggerian withdrawal as [...] disenclosure of Being accompanying the enclosure of being. (Laruelle 2012: 39)

The engine of Difference in Heidegger's ontology-the game of withdrawal, enclosure and disenclosure, or which he calls "clearing" (1971: 53)-reflects the transcendentalization of Flash, completely converting it into thought's model or, as mentioned earlier, the meta-metaphor of light. The Great Photographer, disguised in the mechanics of Being-being clearing, "bringing-forth-to-appearance," which is synonymous with Logos, marks thought's fatal restriction in the light manifesto. Philosophyimperfect witness of light manifestation-can only be the photo-model of the Great Photographer's "session" of clearing, or, to put it in other words, Dasein.

There is some curious detail about the ontic-ontological incarceration of thought. It makes us think that the Heidegger's project-still remaining the culmination of the logo-photo-centric fascination with the Flash-is a kind of axis, by means of which the meteophilosophical movement is possible. We need to adjust Laruelle's suggestion on Heidegger, since the exposition of logo-photo-centrism in fundamental ontology introduces not simply a Flash but the lightning-flash. As Heidegger notes in his essay, "The Turning,"

In the flashing glance and as that glance, the essence, the coming to presence, of Being enters into its own emitting of light [...] And yet that 
glancing, in its giving of light, simultaneously keeps safe the concealed darkness of its origin as the unlighted. The in-turning [Einkehr] that is the lightning-flash of the truth of Being is the entering, flashing glanceinsight [Einblick]. (Heidegger 1977: 45)

The knot between the light and the unlit that binds the lightning and the Flash is to be seen precisely in the strange doubling of work of onticontological Difference. The lightning here is not a mere metaphorical extension of clearing, an additional component to the work of Flash that maintains the Great Photographer. The incorporation of lightning into logo-photo-centric mechanics of Flash destabilizes the model of fundamental ontology. As Eugene Fink points out, "In the view of natural science, lightning is nothing other than a specific electrical appearance." But lightning as the model of ontology suggests the process of "nonphenomenal rising" (Fink, quoted in Heidegger 1979: 104). The non-phenomenomenal dark rising of lightning rejects the lightning as flashing appearance, that is, lightning as manifestation. The lightning-flash that manifests itself, splitting and gathering the multiple (Ibid.: 5), also has to split into the non-phenomenal and phenomenal light, or into the lightning and flash. Lightning that flashes, the lightning-flash, differentiates itself, splitting the initial structure of light manifesto. If Flash in the lightningflash nexus is the basic structure of manifestation entirely working within the logic of absence/presence, or appearance ex nihilo (from the Great Photographer's Photo-process), then the unlit lightning reveals the additional-speculative-dimension of the light manifesto. The Flash remains unexplainable because of the "lateness" of thought (which can assist only in birth, not in creation); it is the facticity of light that we can only fascinate us. Lightning, on the contrary (as we shall see), is about principles that we can investigate, that is, to speculate. Speculation here is a kind of autopsy of entrails of the Great Photographer's apparatus, a way to reveal ex nihilo of Flash as ex mundo of lightning.

While being restricted to the logic of belonging to the Logos-happening, according to which all beings are "those struck by the lightning of logos" (Heidegger 1979: 117), the fundamental ontology reveals a weird dialectics of meta-order-the transcendental order of ontic-ontological Difference maintained by the metaphors of "clearing," "flashing glance," etc.-and the order of darkness, the lightning as "unlighted" and "hidden" part of Difference that is generated not ex nihilo but rather ex mundo, without any transcendence (i.e., without the guarantee of the Great Photographer). This second order-outlining both the "hereness" of lightning and the possibility to investigate it-is the meteo-register that brings a further philosophy to elaborate the model of Difference closer to the very natural science upon which, in the case of Heidegger, it tried to turn its back. 


\section{Dark Precursor}

The paradigmatic type of lightning in physics is a cloud-to-ground discharge. The classical description of its genesis is the following: the dynamics of charged particles produces an electric field that achieves socalled electrical breakdown in the air-a critical increase of electricityproviding a gap conditioning different stages of lightning discharges. "Once electrical breakdown is initiated in a small region, it gives rise to electrical streamer discharges" (Cooray 2015: 92). The streamer is a weak, short-term discharge existing in limited regions; it is branched and filamentary. The streamers may culminate in a so-called leader discharge-a "hot conducting channel" of electrons between cloud and ground, which phenomenally is most frequently associated with the lightning itself. This is the massive flash of light short-circuiting between cloud and ground, accompanied by rumbles of thunder.

The moment of manifestation, the flash of lightning, is thus localized at the "electrical breakdown"-"leader discharge" stage. It is created through the cumulation of small branched flashes (streamer discharges) as a powerful and excessive Flash (leader), a thundering short-circuit between clouds and ground. The Flash (leader) is a product of micro-flashes (streamers), that is in exactly the same, flashing, way, but in a smaller version: manifestation, thus, is a composite of the micro-manifestations.

If Heidegger's philosophy is a philosophy of leader (as the ontic-ontological Difference), the philosophy of difference of Deleuze is, at the first glance, a philosophy of streamers. It unlocks the philosophical shackles of Flash and rejects the totality of the manifestational model by introducing the moment of genesis into it. Lightning in Deleuze's philosophy is not a simple trope nor a model, it is something that is subjected to a certain philosophical investigation. As Braian Massumi points out,

Deleuze writes that a body does not choose to think, and that the supreme operation of thought does not consist in making a choice. A body is "forced to think" by its implication in a self-propagating, serially selforganizing generative movement. Thought strikes like lightning, with sheering ontogenetic force. It is felt. The highest operation of thought is not to choose, but to harbor and convey that force, repotentialized. The thinking is not contained in the designations, manifestations, and significations of language, as owned by a subject [...] The thinking is all along the line. It is the process: its own event. (Massumi 2002: xxxi)

The transcendental manifestation of Difference here is generated by a partial manifestation of differences. The flashing mechanics of thought's expression secularizes the figure of the Great Photographer: the light manifesto is instantiated not only by the sole Photographer, but rather by 
photographers. Deleuze's exploitation of the transcendental mechanics of thought compresses the Great Difference and its Great Manifestation down to the scale of differences and micro-manifestations. The leader (ontic-ontological Difference), which is the clearing of Being, is only a result, by Deleuze's thought, of the streamers (differences). Their game replaces the Great Photographer in the model of the light manifesto. The transcendental meta-order of the latter passes through a secularization process by the suspension of a totality Flash (of a leader).

There is something about Deleuze's philosophy that makes it the true philosophy of lightning or, without any doubt, the first meteophilosophy. If the streamers here still belong to the model of manifestation (likewise the ontic-ontological Difference), there is a principle constituting the order of non-manifestation outside the transcendental flashing light. This principle is the most enigmatic trope of Difference and Repetition-a book that addresses the problem of lightning itself, introducing the fact of its meteo-genesis:

Thunderbolts explode between different intensities, but they are preceded by an invisible, imperceptible dark precursor, which determines their path in advance but in reverse, as though intagliated. Likewise, every system contains its dark precursor which ensures the communication of peripheral series [...] the path it traces is invisible and becomes visible only in reverse, to the extent that it is travelled over and covered by the phenomena it induces within the system, it has no place other than that from which it is 'missing,' no identity other than that which it lacks: it is precisely the object $=\mathrm{x}$, the one which 'is lacking in its place' as it lacks its own identity [...] it perpetually displaces itself within itself and perpetually disguises itself in the series. (Deleuze 1994: 119-20)

The dark precursor is the notion expropriated by Deleuze, by his own words, from a "vaguely scientific" discipline (Stivale 2008: 20). It is a phenomenon that occurs "between two potentials" that "places different potentials into relation" (Ibid.). As the "journey" of the dark precursor takes place, "the potentials enter into a state of reaction from which emerges the visible event [i.e., the manifestation of Flash]" (Ibid.). In the infrastructure of phenomenal lightning (difference/s), a strange "empty place or occupant without place" can be found (Deleuze 1990: 36-41), an order of darkness-the pre-difference-that makes flight from the totality of manifestation by the very degeneration of it. Pre-difference of the dark precursor is able to ground the flash of difference while being separated from it. This is the unilateral distinction, meaning a type of relation where the "distinguished opposes something which cannot distinguish itself from it but continues to espouse that which divorces it" (Ibid: 28). The unilateral model of pre-difference is also executed by Laruelle in decon- 
struction of logo-photo-centrism through the introduction of the "unifacial" model of Flash. The genesis of Flash is "the insurrection or uprising [le soulevement]" based not on the mechanics of difference/s, manifestation, or the "resurrection ex nihilo," but rather on the pre-differential "insurrection ex mundo" (Laruelle 2012: 42). Ex mundo here means the existence of the third principle between the rising and withdrawal of the Flash. The Flash as the model of Difference-rising and withdrawing-is strained between the manifestation as the distinguishing from the sky, and non-manifestation of trailing this sky behind (Deleuze 1994: 28). Great Photographer's transcendence collapses, short-circuiting by the unilateral work of the immanent dark precursor. The pre-differential logic of the dark precursor is a true "formula" of Difference and the core of Deleuze's philosophy of difference rather than the "partial," or microdifferences, which only repeat the model of Heidegger's Difference at a much lower scale. This is why the dark precursor can be treated both as a means of destruction of "conventional" readings of Deleuze and, at the same time, as the destruction of Deleuze's philosophy itself. Through the notion of the dark precursor, Deleuze's philosophy collapses into a practice that cannot (as we shall see in Meillassoux's philosophy) maintain any positivity or creativity. The dark precursor as the dark side of lightnot an illumination but rather the radiation, the imperceptible, but forcible light-suspends the very totality of manifestation by simultaneously constituting the order of non-manifestation that grounds the manifestation but that manifestation cannot manifest. This darkness of the dark precursor switches the questioning from the facticity of manifestation of Flash to its becoming, that is, lightning. Becoming executed by the dark precursor is something that subverts the ontological consistency of Flash by the invisible blank terror of pre-differentiation.

\section{Dark Rays}

The path of meteophilosophy taken by Deleuze was not abandoned. Philosophy's rendezvous with science-where meta- encounters meteo-, the meta-structure (an order of difference/s) of thought encounters the meteo-differentiation of the dark precursor-was reinforced through the replacement of the dark precursor by a principle that is far darker. This principle turns philosophy into a territory where the transcendental completely loses its authority. If philosophy in the case of Deleuze is balancing on the edge of the light manifesto by treating the dark precursor as the ground of mechanics of the Flash without challenging the latter's persistence, the principle we are talking about is the precursor of the very dark precursor, a kind of darkest precursor. It does not just ground, but is also able to cancel the transcendental meta-order of the Flash. In this 
movement of retention of the darkest precursor, philosophy enters a zone where its basic metaphors such as light or space cease their functioning. The dissecting of the phenomenal order of the Flash reveals a sort of principle that makes philosophy turn toward the type of science that simultaneously constitutes something that was once elaborated by Aristotle as "meteorologica" (1952).

The fundamental attitude of meteorology, according to Aristotle's thought, implies that it is a science where "everything which happens naturally but with a regularity less than that of primary element of material things, and which take place in the region which borders most nearly on the movements of the stars" (Ibid.: 5). Meteorology links Chance and the cosmic order with each other and establishes connections between them. By quoting Friedrich Nietzsche, Heidegger claims that "[l]ightning and thunder require time" (Heidegger 1977: 60)-and this could mean that there is a fundamental tension between time and irregularity of lightning that can only be explained from a meteorological perspective, not from the side of metaphysics or even physics. If the first philosophy (metaphysics) works on eternal (i.e., timeless) "principles" such as the unmoved mover, and physics occupies regular things (which are, in that sense, also timeless), only meteorologica elaborates time as that principle which can only provide the possibility of irregularity and contingency of events like lightning. This is why meteo- in the word meteophilosophy refers to the principle of time. But time in meteophilosophy is not a second principle as it was in Aristotle's thought, but is rather the absolute principle. And lightning connecting with time is "not itself in time" but is, on the contrary, "allowing time" (Heidegger 1979: 10). Lightning as time in the case of meteophilosophy becomes a kind of darkest precursor-a speculative ground that can precede not only being, but also the becoming of things (the dark precursor).

The project that discovers the meteorological capacities of the darkest precursor is the speculative project of Quentin Meillassoux. He is working on the absolute-the principle that is radically unbound from the very phenomenal order and the order of presence as such, including its "weak" versions elaborated in contemporary postcritical philosophy. ${ }^{7}$ But that is not all. The absolute is not like "the empty place or occupant without place" in the phenomenal order, a kind of non-phenomenal shortcircuit in the phenomenal. The absolute is not "in between" the Flash, its appearance and withdrawal. The speculative status of Meillassoux's absolute, or the Great Outdoors, is the darkest precursor: it (un)grounds not only Being but also Becoming. This is the meteorological anarchy of hy-

Meillassoux divides this postcritical tendency into the critical movement, which he calls "correlationism," and also speculative movement (especially object-orient ontology), which he calls "subjectalism” (Meillassoux 2012: 7). 
perchaos: its "contingency is so radical that even becoming, disorder, or randomness can be destroyed by it, and replaced by order, determinism, and fixity. Things are so contingent in hyperchaos that time is able to destroy even the becoming of things" (Meillassoux 2014: 25). The Great Outdoors reconstitutes the light manifesto by proposing a sort of a principle that does not reinstate the order of Difference. It requires a dark shift to the principle so radical that even the game of pre-difference (becoming) cannot be reinstated. It is not about the non-luminous conditions of lightning but about the non-luminous itself. The non-luminous, which is indifferent to the game of Difference, that is, the Flash. The Flash is only a surplus, only a contingent effect of the chaotic game of in-difference. So, if Deleuze's difference-the unilateral distinction, pre-difference-is performed between Difference and indifference as the precursor of Difference, here exists an in-difference inside the very difference. This darkest in-difference is a contingent resource of manifesting light and the dark precursor itself. It is not bounded by its "pre," but is radically unbound, or $a b$-solutus. This is a principle in the radical sense of ex mundo that we mentioned above: the pure meteo-order, the meteorological force of time as lightning.

Deleuze's philosophy-balancing on the edge of the Flash-is the half-open door into meteophilosophy. The bond formed between the dark precursor (the scientific notion) and the difference as the unilateral distinction (the philosophical concept) can be simply considered as metaphorical exploitation. But Meillassoux's project pulls this door wide open: philosophy cannot cancel its intimate relations with science. Philosophy does not only expropriate the content from science (to transform it, for example, into a concept). In its very isolated speculative principles, philosophy unwittingly repeats the most marginal tropes of the physics of lightning.

In this regard, we can mention the collapse of the in-differential infrastructure of the Great Outdoors into the theory of the "galactic" genesis of lightning (Stozhkov 2003). According to this theory, lightning generates through the radiation of galactic cosmic rays (GCR). GCR is the flux of the cosmic particles that enter the Earth's atmosphere from deep space-both from the Sun and other stars-and whose energy is the source of ionization in the atmosphere and, as a consequence, of the production of lightning. "As cosmic rays hit the earth's atmosphere accidentally in all directions, the lightning arises by chance also" (Ibid.: 920). This flux of GCR "is enough to explain the amount of lightning observed" (Ibid.). This is a meteorological coup de dés, which will never abolish a chance of Flash. It is an economy of all visible light, but not its cause: the unilateral principle without any, even weak, type of reciprocity.

The model of lightning that is most comprehensively consistent with such cosmic ionization as the Great Outdoors is not the classical lightning 
(which has the breakdown-leader stage and results in an excessive Flash) but ball lightning. Ball lightning is a phenomenon that remains elusive; it "can be formed even inside aircraft and closed rooms, permeate glass plates, decay explosively or silently, and produce sound and acrid odours" (Wu 2016: 1). The mechanics of ball lightning, in fact, has no particular genesis or cause. It can be produced without manifestation: it appears in a more radical sense of ex mundo, as a given radiance, as a product of a permanent galactic coup de dés. But ball lightning is also relevant because it is a very rare phenomena, existing in a peculiar optical "mythology." "Ball lightning has not been produced in the laboratory and the authenticity of the available photographs is questionable, the properties of ball lightning must be extracted from eyewitness accounts" (Cooray 2015: 365). Being a dangerous phenomenon, contact with which "sometimes leads to unpleasant consequences for accidental witnesses," ball lightning "provides a ground for creating myths" like the ability to "penetrate through window glass leaving it unaffected and to leap out of radio and electric sockets," the myths which are also circulated between certain Russian physicists (Grigor'ev, Grigor'eva and Shiryaeva 1992). So, ball lightning thus marks the pure order of "meteo"-while being a product of the darkest chaotic ionization, it is completely incompatible with the transcendental order of thought. Ball lightning might as well be an illusion, a phantasm for the eye, as well as an undetectable and random physical phenomenon: in both cases there is phenomenon without any guarantee or regularity, indifferent and alien to thought's transcendental constitution. The Great Outdoors constitutes the order that is outside the photo-process of the Great Photographer; it is outside thought and the world itself. This is the raging force of the radically immanent ex mundo, "the universe in which disorderly modifications are so frequent that conditions of [...] consciousness would be abolished" (Meillassoux 2015: 40).

\section{Dark Effects}

The present examination of Meillassoux and Deleuze's projects clearly demonstrates the total uncoupling of the meteo-order of lightning from the meta-order of the Flash within the meteophilosophical practice of thought. Whereas the Flash makes philosophy remain in the transcendental totality of the light manifesto, lightning, in the case of meteophilosophy, obtains the anti-manifestational status (which can be grasped, for instance, by the model of ball lightning). As a result, lightning nullifies the theology of the Great Photographer. Before meteophilosophy, the Great Photographer was a kind of paparazzi, that is, a photographer whose identity is unknown and whose photos are always-already there before the act of photographing. But meteophilosophy manages to catch the Great 
Photographer in the act and investigate their photo-technics. Basically, lightning is the inner side of the Great Photographer's camera and the Great Photographer itself. The Great Outdoors, or the darkest precursor, deciphers this inner side of the apparatus of the light manifesto, and excavates the anti-manifestational principles of the Flash genesis.

Meteophilosophy, we find, is not an x-philosophy like geophilosophy. This is an extreme practice of thought that, by mixing philosophy and science, in the end turns into a practice of meteorologica, which transforms from the simple science of non-regular events into a speculative alternative to "first philosophy" (or "first science") that works with primary-absolute-principles. Meteophilosophy attempts to disentangle itself from the logo-photo-centric limit through an investigative impulse that eliminates the photographical passivity of philosophy as imprisoned in the totality of the "Great Photographer."

Yet, there is a serious problem that has to do with the meteophilosophical abandonment of the light manifesto and the logo-photo-centric model in general. Meteophilosophy uncovers the anti-manifestational principles of manifestation (precursors of the Flash) lancing the entrails of the Great Photographer's apparatus. But at the same time, meteophilosophy doesn't change the actual mechanics of manifestation. The totality of the logo-photo-centric Flash by which philosophy is imprisoned in the case of meteophilosophy cannot mutate or be transformed but can only be cancelled. As Meillassoux notes, through the principle of hyperchaos we can imagine a regressive sequence of worlds "in which disorderly modifications are so frequent that": science and consciousness are still possible; science (based on regularity of law) is abolished but consciousness is still possible; both science and consciousness are abolished (Meillassoux 2015:24-40). This is the detranscendentalization of thought, the critique of logo-photo-centric thought as well as abandonment of thought itself. Futhermore, consciousness without laws-a pure inconsistent imagination-is still subordinate to the transcendental diktat of law, "albeit in a negative mode" (Meillassoux 2015: 44; Kuchinov 2019). In other words, the meteophilosophical storm of inconsistent (i.e., unlit) and disordered darkness only abolishes thought instead of detranscendentalizing its luminous mechanics. Meteophilosophy in the cases of Meillassoux and Deleuze does not destruct the light manifesto but only reveals that it is rooted in absolute non-manifestation. This is an elaboration of light manifesto, a development of a kind of light manifesto 2.0.

In the case of the light manifesto 1.0, the description of logo-photocentric thought as suggested by Laruelle, we have the pure "meta-," or a strict and total order of the Flash. In the case of the light manifesto 2.0, on the other hand, we have a pure "meteo-," the contingent force of lightning which is still compatible with the Flash. We approach the light manifesto, the structure of lightning-flash, from two different sides: from the side of 
the lightning and from the side of the Flash. But they remain unconnected and represent two other ways to describe the light's manifestation. This is why we need to work on the connection, on the "-" in the structure of the lightning-flash, both neglected by meteophilosophy and logo-photo-centrism.

The historical situation in which lightning encountered the flash, the meteo- linked to the meta-, first happened in 1899. In that year, physicist Robert Williams Wood wrote a letter to Nature. He described an unusual lightning, a "rare phenomenon" that was captured by few photographs. He wrote about "a flash which appears darker than the sky behind it." These dark flashes, according to Wood, could not be explained by collateral phenomena such as "preponderance of infra-red radiations." They were, on the contrary, something that "appeared to be a reality" (Wood 1899a: 460). In his letter, Wood kept the dark lightning unexplained, noting that "it will be impossible to formulate even a reasonable guess as to the cause of these dark flashes" (Ibid.).

After some time, Wood was immediately criticized because of an existing explanation by another physicist-A.W. Clayden. He asserted that the darkness of lightning in Wood's shots is a purely photographical paradox, "a peculiar photographic reversal," which means that "it only remains to explain his [Clayden's] explanation”:

Mr. Clayden showed that if a plate, which had received an impression of a lightning flash or electric spark, was subsequently slightly fogged, either by exposing it to feeble diffused light or by leaving the lens of the camera open, the flash on development came out darker than the background. If, however, the plate was fogged before the image of the flash was impressed, it came out brighter than the background, as in the ordinary pictures of lightning. (Wood 1899b: 717-19)

Dark lightning is not a new phenomena: it is "not a new type of lightning but a result of the Clayden effect” (Orville 1972: 111). After all, the tension between Clayden and Wood migrated into photographic theory and then turned completely into a purely photographic paradox known as the Clayden effect (Mees 1942: 254). In the case of the Clayden effect, we are dealing with the mechanism of reversal, when the initial phenomenon of lightning is inverted by its simulacra (a shot of dark lightning). The very exact paradoxical reversal, dark lightning inverts only lightning, but not the background of the sky behind its appearance. This is the inner game of lightning and its shot, the result of the manifestation of the non-manifestible, the dark effect that arises from the breakdown of manifestation, the overexposure of the Great Photographer's shot.

This dark effect-the result of the breakdown of the manifestationcan also be traced in the contemporary physics of lightning. Between 
1991 and 1993, Compton Gamma Ray Observatory, which specializes in gamma ray research, discovered a strange phenomenon. Besides all data including the cosmic flashes of gamma rays, solar flares, and so on (as mentioned earlier in the case of GCR), additional, non-cosmic flashes were registered. Flashes that arrive not from the meteorological Great Outdoors, but from the Earth itself. It was immediately associated with lightning and, subsequently, in 2013 an enigmatic event resulted in a hypothesis about so-called TGF-terrestrial gamma flashes-also known as "dark lightning." These types of flashes were not associated with lightning correlatively, but rather genetically:

Our observations show that this weak and short TGF [...] was produced deep in the thundercloud at the initial stage of a [...] IC [intra-cloud] lightning propagating upward before the leader [i.e., Flash, or the "bright" lightning] reached the cloud top and extended horizontally. A strong radio pulse that was detected and geolocated coincidently with the TGF was most likely produced by the TGF itself. This is the first time the sequence of radio pulses, TGF and optical emissions in an IC lightning flash has been identified. (Østgaard, et al. 2013)

TGF are manifestations that appear separately from the manifestations of usual lightning "during its initial phase" (Ibid.) They are the physical activity that produce its own flash, but a flash without any light, a kind of dark manifestation. TGF do not come after normal lightning like Wood's dark lightning (appearing only on photographs). TGF are a kind of initial malfunction in the process of manifestation. If the Clayden effect, resulting from the overexposure of a photo, is about a kind of hyper-manifestation, TGF is more about an initial error in manifestation, manifestation-without-manifested, like photographing with a closed camera lens.

In the case of the Clayden effect and TGF, the Great Outdoors faces the Great Photographer. These dark effects-“-” in the structure of the lightning-flash-are degenerated both from the precursor's in-difference and the Difference of the Flash. They refer to a strange gap between the darkness of non-manifestation and the Flash of manifestation. This gap in the history of photography was named the "birdie."

"The sitter forgets all about the head-rest, the trying light, the wearisomeness of keeping a fixed position [...] . A pleasant and unconscious expression on the face of the sitter is the result of the little bird's melody." Soon photographers could buy a mechanical bird that chirped when a pneumatic bulb was squeezed-and "watch the birdie" became a command at portrait sessions. (Hirsch 2017: 177) 
The birdie in the phrase "watch the birdie," the moment of delay between the shutter release and the flash of the camera, is a speculative model glimmering between darkness and light, between lightning and the Flash. If the constitution of precursors-pre-difference and in-difference-belongs to the domain of unilateral radiance, or something that precedes and generates light without belonging to it, the status of dark effects suggests the monstrous surplus of light and darkness. The birdie, also related to the Thunderbird-the mythic creature of North American indigenous culture that brings lightning ${ }^{8}$ - is both before and after the manifestation. Meta- links to the meteo- in the paradoxical, neither transcendental nor speculative impulse of this (thunder)birdie. Conditioning and mediating both speculative and transcendental levels, the birdie does not belong to any of them. The principle of the birdie is neither Great Photographer's transcendence nor Great Outdoors' precursory immanent unilaterality. This is something we can call non-laterality, degenerated from any principle that can itself be treated as principle.

The (thunder)birdie is the true anti-manifestational movement that can bring to collapse the logo-photo-centric structure of light manifesto. The model of Wood's dark lightning constitutes the thought with the failed Logos, non-photocentric logocentrism, Logos without light through which it was being born, and the TGF model refer to the photo-centrism without Logos, the Flash without thought that fascinates its event. But at the same time, the birdie corresponds to the abandonment of Plato's Cave, an endless repetition of the process of stepping-into-the-light. The work of the (thunder)birdie, the bastard born through the alliance of philosophy and science-both Sisyphean toil of light generation and the Promethean tortures of effect of light-thus constitutes the worst lightmares of thought.

\section{References}

Aristotle (1952). Meteorologica. Trans. H. D. P. Lee. Cambridge, MA: Harvard University Press.

Braidotti, Rosi (2013). The Posthuman. Cambridge: Polity Press.

Brassier, Ray (2001). "AlienTheory: The Decline of Materialism in the Name of Matter" PhD thesis, University of Warwick, http://wrap.warwick.ac.uk/ 4034/1/WRAP_

8 A good description of the thunderbird can be found in Neil Gaiman's American Gods: "A trail of lightning speared across the clouds, and Shadow wondered if that was the thunderbird returning to its high crags, or just an atmospheric discharge, or whether the two ideas were, on some level, the same thing. And of course they were. That was the point, after all” (Gaiman 2001: 414). 


\section{For Deleuze}

THESIS_Brassier_2001.pdf

Brassier, Ray (2007). Nihil Unbound: Enlightenment and Extinction. Basingstoke: Palgrave Macmillan.

Cooray, Vernon (2015). An Introduction to Lightning. Dordrecht: Springer.

Cybernetic Culture Research Unit (2017). CCRU Writings, 1997-2003. Falmouth: Urbanomic Media.

Deleuze, Gilles (1994). Difference and Repetition. Trans. Paul Patton. New York: Columbia University Press.

Deleuze, Gilles (2007). "Mathesis, Science and Philosophy." Collapse 3: 141-55.

Deleuze, Gilles, and Félix Guattari (1987). A Thousand Plateaus. Capitalism and Schizophrenia. Trans. Brian Massumi. Minneapolis: University of Minnesota Press.

Deleuze, Gilles, and Félix Guattari (1994). What is Philosophy? [1991]. Trans. Hugh Tomlinson and Graham Burchell. New York: Columbia University Press.

Derrida, Jacques (1978). Writing and Difference. Trans. Alan Bass. Chicago: The University of Chicago Press.

Descartes, René (2006). Discourse Method of Correctly Conducting Ones Reason and Seeking Truth in the Sciences. Trans. Ian Maclean. Oxford: Oxford University Press.

Descartes, René (2008). Meditations on First Philosophy: with Selections from the Objections and Replies. Trans. Michael Moriarty. Oxford: Oxford University Press.

Gaiman, Neil (2001). American Gods. New York: HarperCollins Publishers.

Galloway, Alexander (2013). "Laruelle and Art." Continent 2.4: 230-36.

Gironi, Fabio (2011). "Meillassoux’s Speculative Philosophy of Science: Contingency and Mathematics.” Pli: The Warwick Journal of Philosophy 22: 25-60.

Grigor’ev, A. I., I. D. Grigor'eva, and S.O. Shiryaeva (1992) "Ball Lightning Penetration into Closed Rooms: 43 Eyewitness Accounts.” Journal of Scientific Exploration 6.3: 261-79.

Heidegger, Martin (1977). The Question Concerning Technology, and Other Essays. Trans. William Lovitt. New York: Garland Publishing.

Heidegger, Martin (1971). Poetry, Language, Thought. Trans. Albert Hofstadter. New York: Harper \& Row.

Heidegger, Martin (1979). Heraclitus Seminar 1966/67. Trans. Charles H. Seibert. Tuscaloosa: The University of Alabama Press.

Hirsch, Robert (2017). Seizing the Light: a Social \& Aesthetic History of Photography. New York : Routledge, Taylor \& Francis Group.

Hörl, Eric ed. (2017). General Ecology: The New Ecological Paradigm. New York: Bloomsbury.

Kuchinov, Eugene (2019).. "Fictio Audaciae: po tu storonu samosohraneniya Prosveshcheniya." [Fictio Audaciae: beyond self-preservation of the Enlightenment]. Logos 4.

Kurath, Hans, Sherman M. Kuhn, and Robert Lewis (1952). Middle English Dictionary. Ann Arbor: University of Michigan Press.

Land, Nick (1992). The Thirst for Annihilation. George Bataille and Virulent Nihilism. London: Routledge.

Land, Nick (2011). Fanged Noumena: Collected Writings 1987-2007. Falmouth: Urba- 


\section{Nikita Sazonov}

nomic.

Laruelle, François (2012). Photo-Fiction, A Non-Standard Aesthetics. Trans. Drew S. Buck. Minneapolis: Univocal Publishing.

Laruelle, François (2013a). Philosophy and Non-Philosophy. Minneapolis: University of Minnesota Press, Univocal Publishing.

Laruelle, François (2013b). Principles of Non-Philosophy. New York: Bloomsbury Academic.

Massumi, Brian (2002). A Shock to Thought: Expression After Deleuze and Guattari. London: Routledge.

Mees, Charles Edward Kenneth (1942). The Theory of the Photographic Process. New York: Macmillan.

Meillassoux, Quentin (2012). “Iteration, Reiteration, Repetition: A Speculative Analysis of the Meaningless Sign.” Freie Universität, Berlin, 20 April, 2012. https://cdn. shopify.com/s/files/1/0069/6232/files/Meillassoux_Workshop_Berlin.pdf

Meillassoux, Quentin (2014). Time Without Becoming. Milan: Mimesis International.

Meillassoux, Quentin (2015). Science Fiction and Extro-Science Fiction. Minneapolis: University of Minnesota Press, Univocal Publishing.

Morton, Timothy (2013). Hyperobjects: Philosophy and Ecology after the End of the World. Minneapolis: University of Minnesota Press.

Negarestani, Reza (2008). Cyclonopedia: Complicity with Anonymous Materials. Melbourne: Re.Press.

Negarestani, Reza (2018). Intelligence and Spirit. Falmouth: Urbanomic.

Sokal, Alan, and Jean Bricmont (1999). Fashionable Nonsense: Postmodern Intellectuals' Abuse of Science. New York: Picador.

Stivale, Charles (2008). Gilles Deleuze's ABC. The Folds of Friendship. Baltimore: Johns Hopkins University Press.

Stozhkov, Yuri (2003). “The Role of Cosmic Rays in the Atmospheric Processes.” Journal of Physics G: Nuclear and Particle Physics 29.5: 153-68.

Orville, Richard (1972). "Lightning between Clouds and Ground.” Weatherwise 25.3: 108-111.

Østgaard Nikolai, Thomas Gjesteland, Brant Carlson, Andrew Collier, Steven Cummer, and Hugh Christian (2013). "Simultaneous Observations of Optical Lightning and Terrestrial Gamma Ray Flash from Space.” Geophysical Research Letters 40.10: 2423-26.

Tripodi, Benedetta (2015). “Ontology, Neutrality and the Strive for (non-)Being-Queer.” Badiou Studies Vol. 4 N 1: 72-102. https://f.hypotheses.org/wp-content/blogs. dir/1647/files/2016/03/100-337-1-PB.pdf

Wood, Robert (1899a). “Dark Lightning.” Nature 60.1559: 460-61.

Wood, Robert (1899b). “On the Cause of Dark Lightning and the Clayden Effect.” Nature 61.1570: 104-05.

Wu, Hui-Chun (2016). "Relativistic-Microwave Theory of Ball Lightning." Nature. Scientific Reports 6.28263. https://www.nature.com/articles/srep28263.pdf.

Youngson, Robert (2005). Collins Dictionary of Medicine. Glasgow: Collins. 